\title{
Australian Journal of \\ Crop Science
}

AJCS 14(01):1-6 (2020)

doi: 10.21475/ajcs.20.14.01.p1328

\section{Coffea arabica cultivars with resistance to nematode Meloidogyne exigua originated from Costa Rica}

\author{
Mainor Rojas Barrantes ${ }^{1}$, Daniel Ramírez Valerio $^{1}$, Luis Salazar Figueroa ${ }^{2}$, Tumoru Sera ${ }^{3}$, Gustavo Hiroshi \\ Sera $^{3^{*}}$
}

${ }^{1}$ Instituto del Café de Costa Rica (ICAFE), Heredia, Costa Rica

${ }^{2}$ Laboratorio Nemafito, San José, Costa Rica

${ }^{3}$ Instituto Agronômico do Paraná (IAPAR)/ Plant Breeding Department. Rodovia Celso Garcia Cid Km 375 . CEP 86047-902, Três Marcos, PO Box 481, Londrina, PR, Brazil

\section{*Corresponding author: gustavosera@iapar.br}

\begin{abstract}
The nematode Meloidogyne exigua causes moderate losses in almost all coffee plantations in Costa Rica. The objective of this research was to evaluate the resistance of Coffea arabica cultivars developed in Brazil to M. exigua native from Costa Rica. The trial was carried out in Heredia, Costa Rica. A randomized complete block design with five replications was used to evaluate the cultivars Caturra, Catuaí Vermelho IAC 99, IAPAR 59, IPR 98, IPR 99, IPR 100, IPR 102, IPR 103, IPR 106 and IPR 107. The plants were grown in pots and inoculated with 2500 eggs $+J_{2} 117 \mathrm{~d}$ after the transplant. The evaluation was performed $209 \mathrm{~d}$ after the inoculation considering the number of eggs $+J_{2}$ in $100 \mathrm{~g}$ of roots and the estimation of gall index (GI) of each plant. The reduction in the reproduction factor showed resistance for the cultivars IPR 99, IPR 100, IPR 102, IPR 103 and IPR 107. This represents a great possibility to face M. exigua of Costa Rica in a sustainable way with varieties developed in Brazil.
\end{abstract}

Keywords: Coffee, genetic breeding, root-knot nematode, IPR.

Abbreviations: Instituto Agronômico de Paraná_IAPAR; Centro de Investigaciones en Café _CICAFE; IP_initial population; FP_final population; gall index_Gl; RF_reproduction factor; J2_second stage juveniles; RRF_reduction in the reproduction factor; HS_highly susceptible; S_susceptible; MS_moderately susceptible; MR_moderately resistant; R_resistant; HR_highly resistant; TH_Timor Hybrid.

\section{Introduction}

In Costa Rica, around 84000 ha is cultivated with coffee (INEC, 2015), in 8 zones with different characteristics of climate, altitude and the soils. It is estimated that $80 \%$ of the cultivars used correspond to Caturra and Catuaí, which practically all the genetic materials are susceptible to nematodes of the Meloidogyne Chitwood genus. In the plantations, the presence of Meloidogyne exigua (Salas and Echandi, 1961; ICAFE, 1998), M. arabicida (López and Salazar, 1989; ICAFE, 1998), M. javanica, $M$ incognita, $M$. enterolobii (Hernández, 2007) and M. lopezi (Humphreys et al., 2014) has been reported.

In almost all coffee plantations in Costa Rica, there are moderate populations of the genus Pratylenchus, while in some isolated places high population of $M$. arabicida and $M$. exigua has been reported throughout the country (Rojas, 2010), constituting the most important species. The distribution of M. exigua in coffee plantations is also wide in Brazil (Gonçalves and Silvarolla, 2007), Colombia (Leguizamón and López, 1972; Baeza et al., 1978) and Central America (Hernández, 2007).
In plantations under five yr of age in Rio de Janeiro, Brazil, the loss at the field level could reach $13 \%$, with population levels of $M$. exigua between 10 and $15 \mathrm{~J}_{2} / 100 \mathrm{~cm}^{3}$ of the soil (Barbosa et al., 2004). In Costa Rica, Bertrand et al. (1998) estimated that $M$. exigua can reduce production by up to $15 \%$. At the greenhouse level, Rojas and Salazar (2013) reported that the pathogen could affect all the growth variables from an initial inoculum of 0.125 eggs $+J_{2} / \mathrm{cm}^{3}$ of substrate.

Chemical control with nematicides has not been satisfactory (Jaehn et al., 1984; Alpizar et al., 2006; Marcolan et al., 2009) and genetic resistance seems to be the best way to control the root-knot nematodes (Villain et al., 1999; Alpizar et al., 2006; Ito et al., 2008). It has been determined that the resistance to $M$. exigua in several lines of $C$. arabica derived from the Timor Hybrid comes from Coffea canephora (Bertrand et al., 2001) and that it is controlled by a major gene called Mex-1 (Noir et al., 2003).

Some of the cultivars developed by the IAPAR have shown resistance to Meloidogyne spp. (Salgado et al., 2005; Ito et al., 2008; Silva et al., 2010; Dias-Arieira et al., 2012; Sera et 
al., 2017) and represent an important tool to face this plague in a sustainable way. The cultivars of IAPAR are derived from Sarchimor and Icatu, which are sources of resistance to $M$. exigua (Bertrand et al., 1997; Gonçalves and Pereira, 1998; Silvarolla et al., 1998; Salgado et al., 2005). Of the IAPAR cultivars, only IAPAR 59 (Salgado et al., 2005) and IPR 100 (Rezende et al., 2017) were identified as resistant to $M$. exigua populations in Brazil. So far, only IAPAR 59 was tested for resistance to $M$. exigua from Costa Rica (Bertrand et al. 1998, Anthony et al. 2005, Alpizar et al. 2006).

The objective of this research was to evaluate the resistance of Coffea arabica cultivars developed in Brazil to M. exigua native from Costa Rica.

\section{Results and discussion}

\section{Gall index}

The average of gall index (GI) clearly separated four groups of cultivars (Fig. 1). In the susceptible cultivars Caturra and Catuaí Vermelho IAC 99, M. exigua managed to develop galls in more than $50 \%$ of the root system. In field conditions, high level of galls would quickly affect the development of the root system, the productivity and the plant's disposition to resist biotic and abiotic conditions that arise in the production system. The cultivar IPR 106 showed galls in more than $25 \%$ of roots, which will cause deterioration of the plant in the long term. Under field conditions, roots with galls tend to rot and; therefore, the root system and its capacity to absorb water and nutrients are reduced. The cultivars IPR 98, IPR 99, IPR 100, IPR 102, IPR 103, IPR 107 and IAPAR 59 standing out due to their low level of galls (less than $25 \%$ ). These seven cultivars develop by IAPAR showed very good resistance to the development of galls despite the good initial inoculum and the months that these young plants were exposed to the nematode.

The Gl obtained in each of the evaluated plants showed the segregation or genetic homogeneity of the cultivars for this variable (Fig 2). The susceptible cultivars Caturra and Catuaí Vermelho IAC 99 showed around $90 \%$ and $70 \%$ of the plants with $\mathrm{Gl}$ of 4 and 5 , respectively (galls in more than $50 \%$ of roots). The IPR 106 showed low resistance level to gall formation and high segregation, since it presented relatively high percentages of plants in all grades of the GI. On the other hand, cultivars IPR 99, IPR 107, IPR 102 and IPR 103 showed more than $90 \%$ of the plants with $\mathrm{Gl}$ of 1 , indicating their good uniformity and high resistance to gall formation by Costa Rican M. exigua.

\section{Population density}

The population density variable of the nematode in the roots showed three clearly separated groups of cultivars (Fig 3, Table 1), with the IPR 98, IPR 99, IPR 100, IPR 102, IPR 103, IPR 107 and IAPAR 59 standing out due to low population of nematodes. In the roots of these cultivars, the nematode densities were oscillated between 3600 and $17600 \mathrm{~J}_{2} / 100 \mathrm{~g}$ of root, compared to densities between 210000 and 230800 $\mathrm{J}_{2} / 100 \mathrm{~g}$ of root of Catuaí Vermelho IAC 99 and Caturra, respectively. The IPR 106 was presented with an average population density of $111200 \mathrm{~J}_{2} / 100 \mathrm{~g}$ of root, showing a good relationship with the $\mathrm{Gl}$.
Only during the development of the nursery, populations of M. exigua higher than $200000 \mathrm{~J}_{2} / 100 \mathrm{~g}$ of root can cause losses of $50 \%$ of the aerial weight of the plants (Rojas and Salazar, 2013).

\section{Reproduction factor}

In congruence with the population density, three groups were statistically separated for RF: Caturra and Catuaí Vermelho IAC 99 with 92 and 84, respectively; IPR 106 with 44 and the other cultivars with less than 7 (Table 1). The results of RF for the susceptible cultivars of this trial are similar (Carneiro et al., 2008) or higher (Salgado et al., 2005; Silva et al., 2007; Muniz et al., 2009) than those reported in other trials for susceptible cultivars, indicating optimal conditions to obtain reliable results. Anthony et al. (2005) in a similar trial reported that the nematode extracted from the same site (CICAFE) on IAPAR 59 caused hypersensitivity reaction in the radical cells affected by the nematode, abnormal nematodes, lower reproductive rate and reduction in penetration, compared to Caturra.

Cultivars IPR 98, IPR 99 and IPR 107 would have inherited the Mex-1 gene from TH 832/2, the same as IAPAR 59, while cultivars IPR 102 and IPR 103 would have inherited the resistance of $C$. canephora from of the Icatu. The resistance of the IPR 100 might have come from the C. liberica. However, the source of resistance in the BA-10 and the responsible genes is unknown.

In relation to Caturra, the RRF for Catuai Vermelho IAC 99 was $9 \%$ and for the IPR 106 it was $52 \%$. Meanwhile, for the other cultivars it was greater than $92 \%$. The RRF of the IAPAR 59 of this trial is the same as that reported by Salgado et al. (2005), showing the stability of this genotype.

The high reproduction rate of $M$. exigua in the susceptible cultivars grown in Costa Rica is impacting the productivity and economic development of coffee farmers. Again, the use of varieties of the IAPAR with low reproductive rate of the nematode will represent a great alternative for the country.

\section{Resistance}

Based on the RRF values (Shigueoka et al., 2017), the cultivars Caturra, Catuaí Vermelho IAC 99 and IPR 106 were classified as S to Costa Rican M. exigua. The IAPAR 59 and the IPR 98 were classified as $R$; while the rest of the cultivars evaluated (IPR 99, IPR 100, IPR 102, IPR 103 and IPR 107) were classified as HR (Table 1 ). The results of this test corroborate the susceptibility of Caturra and Catuaí Vermelho IAC 99 to $M$. exigua, as well as the resistance of IAPAR 59 to this nematode. The resistance of IAPAR 59 to $M$. exigua has also been verified by Alpizar et al. (2006) and Bertrand et al. (1998) in Costa Rica, by Dias et al. (2009) and Salgado et al. $(2002,2005)$ in Brazil.

Despite the resistance observed in IAPAR 59, the FR was > 1.0, unlike the study by Muniz et al. (2009), in which this cultivar presented $\mathrm{FR}<1.0$ for two populations of $M$. exigua. The other cultivars classified as R or HR also showed FR > 1.0. This indicates that the population of $M$. exigua of Costa Rica used in our study may be more aggressive for those cultivars with resistance than the study by Muniz et al. 
Table 1. Classification of resistance levels of coffee cultivars to M. exigua. Heredia, Costa Rica. 2016.

\begin{tabular}{lcccc}
\hline Cultivar & $\begin{array}{c}\text { Population density } \\
\left(\mathrm{J}_{2} / 100 \mathrm{~g} \text { root }\right)^{\dagger}\end{array}$ & $\begin{array}{c}\text { Reproduction } \\
\text { factor }\end{array}$ & $\begin{array}{c}\text { Reduction in reproduction factor } \\
(\%)\end{array}$ & Classification \\
\hline Caturra & $230800 \mathrm{a}$ & $62.32 \mathrm{a}$ & 0.00 & Susceptible \\
Catuaí & $210000 \mathrm{a}$ & $84.00 \mathrm{a}$ & 9.01 & Susceptible \\
IPR 106 & $111200 \mathrm{~b}$ & $44.48 \mathrm{~b}$ & 51.82 & Susceptible \\
IPR 98 & $17600 \mathrm{c}$ & $7.04 \mathrm{c}$ & 92.37 & Resistant \\
IAPAR 59 & $14400 \mathrm{c}$ & $5.76 \mathrm{c}$ & 93.76 & Resistant \\
IPR 107 & $6800 \mathrm{c}$ & $2.72 \mathrm{c}$ & 97.05 & Highly resistant \\
IPR 102 & $6000 \mathrm{c}$ & $2.40 \mathrm{c}$ & 97.40 & Highly resistant \\
IPR 100 & $4200 \mathrm{c}$ & $1.68 \mathrm{c}$ & 98.18 & Highly resistant \\
IPR 99 & $3600 \mathrm{c}$ & $1.44 \mathrm{c}$ & 98.44 & Highly resistant \\
IPR 103 & $1800 \mathrm{c}$ & $1.92 \mathrm{c}$ & 97.92 & Highly resistant \\
\hline
\end{tabular}

$\boldsymbol{T}$ Within columns, means followed by the same letter are not significantly different according to Fisher LSD test $(\alpha=0.05)$.

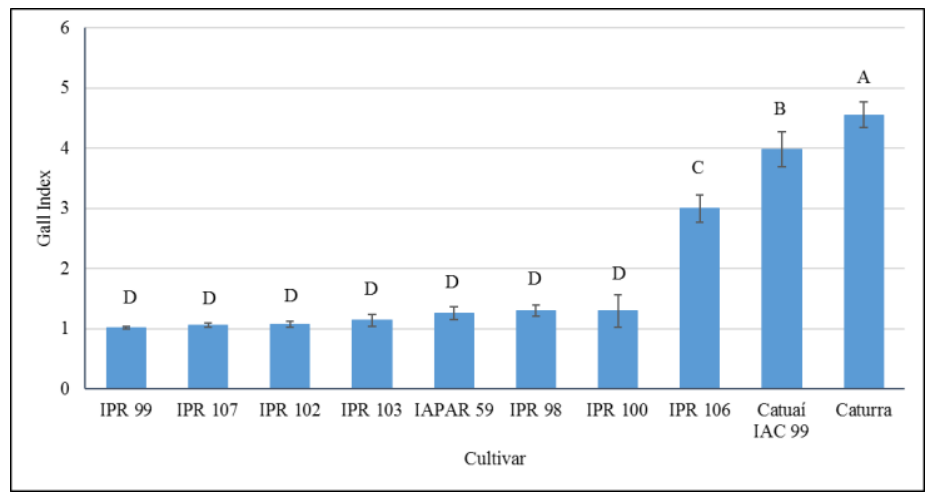

Fig 1. Gall index (GI) caused by M. exigua according to the cultivar evaluated. Different lowercase letters above the bar indicate significant at $\mathrm{P}<0.05$.

Table 2. Arabica coffee cultivars evaluated against Meloidogyne exigua. Heredia, Costa Rica. 2016.

\begin{tabular}{ll}
\hline Cultivar & Origin \\
\hline Caturra (susceptible control) & Natural mutation of Bourbon \\
Catuaí Vermelho IAC 99 & Caturra 476-11 x Mundo Novo IAC 374-19 \\
IAPAR 59 & Villa Sarchí 971/10 x TH 832/2 \\
IPR 98 & Villa Sarchí 971/10 x TH 832/2 \\
IPR 99 & Villa Sarchí 971/10 x TH 832/2 \\
IPR 100 & Catuaí x (Catuaí x BA 10) \\
IPR 102 & Catuaí x Icatu \\
IPR 103 & Catuaí x Icatu \\
IPR 106 & Icatu \\
IPR 107 & (IAPAR 59 x Mundo Novo IAC 376-4) \\
\hline
\end{tabular}

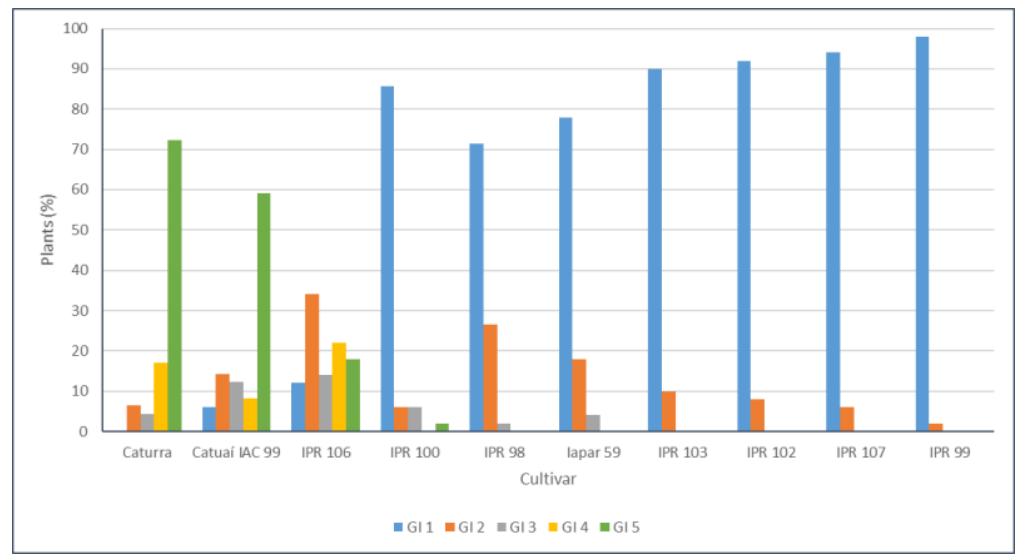

Fig 2. Percentage of plants with different Gall Index (GI) caused by M. exigua according to the cultivar evaluated. 
Table 3. Qualitative scale used to determine the gall index.

\begin{tabular}{ll}
\hline Gall Index & Percentage of the root system with galls \\
\hline 1 & $0 \%$ \\
2 & $1-25 \%$ \\
3 & $26-50 \%$ \\
4 & $51-75 \%$ \\
5 & $76-100$ \\
\hline
\end{tabular}

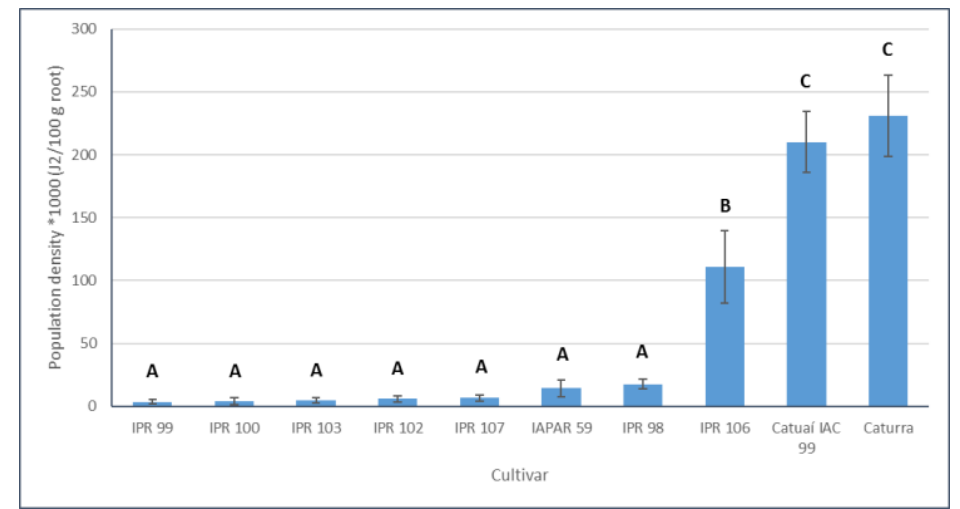

Fig 3. Population density of $M$. exigua according to the cultivar evaluated. Different lowercase letters above the bar indicate significant at $\mathrm{P}<0.05$.

(2009). According to Salgado et al. (2005), this resistance is a post-infectious type due to the presence of eggs and galls in the roots. In addition, this presence would be responsible for triggering the coffee tree defense process through the interaction between substances produced by the nematode and the plant cell from the beginning of the penetration. Muniz et al. (2009) reported that a population of $M$. exigua from Rio de Janeiro reached a reproduction factor of 165.7, surpassing the resistance conferred by the Mex-1 gene. Another hypothesis of our study is that the qualitative resistance of IAPAR 59 and IPR 98 was broken down by this population of $M$. exigua, but the quantitative resistance is acting to decrease the nematode reproduction.

Regarding the resistance reaction of a Catimor to $M$. exigua at cellular level, Rodrigues et al. (2000) reported that the nematode may induce chromatin condensation, alteration of carbohydrate metabolism, development of lysosomes and autophagic vacuoles, causing necrosis of damaged root cells as a possible hypersensitivity response. All these led to cell death six days after infection.

The resistance of the IPR 100 was also tested in this research. This cultivar was recently reported in Brazil as resistant to $M$. exigua (Rezende et al., 2017), to $M$. paranaensis (Ito et al., 2008; Andreazi et al., 2015; Sera et al., 2017) and $M$. incognita races 1 (Kanayama et al., 2009) and 2 (Ito et al., 2008). This simultaneous resistance to several nematodes is of extreme importance, as it is common to find mixtures of Meloidogyne species and races in coffee crops.

The IPR 106 was reported as resistant to $M$. paranaensis and $M$. incognita race 2 (Ito et al., 2008) but susceptible to $M$. exigua from Costa Rica. This result is very important for the selection of cultivars to be grown in a region contaminated with the Meloidogyne species and shows genetic differences between the cultivars IPR 102 and IPR 103, despite coming from the same crossing (Catuaí x Icatu). Pereira et al. (2012) evaluated genotypes resulting from the crossing of Icatu or Catuai with the $\mathrm{TH}$ or Catimor against $M$. exigua and reported them as mostly susceptible. Therefore, it is possible that IPR 106 has resistance genes to $M$. paranaensis and $M$. incognita, but not to $M$. exigua, probably due to hostpathogen interactions. This observation had already been made by Hernández et al. (2004), Carneiro et al. (2008) and Muniz et al. (2009). The resistance found in cultivars IAPAR 59, IPR 98 and IPR 99, was probably originated from the TH $832 / 2$, whereas from IPR 107 from the parent IAPAR 59, since Mundo Novo is susceptible. Icatu can be the source of resistance of cultivars IPR 102, IPR 103 and IPR 106, while IPR 100 can be coffee BA-10. Other studies also report that derivatives of Timor Hybrid (Bertrand et al., 1997; Gonçalves and Pereira, 1998) and Icatu (Silvarolla et al., 1998) are sources of resistance to $M$. exigua. In Brazil, the cultivars identified as resistant to $M$. exigua are IAPAR 59 (Muniz et al., 2009), IAC 125 RN, MGS Catiguá 3, Catucaiam 78515, Catucaí 785-15 and Acauã (Pereira and Baião, 2015). This study demonstrated the resistance of IPR 98, IPR 99, IPR 102, IPR 103 and IPR 107 to M. exigua native from Costa Rica, which will be new planting options for areas infested with this nematode.

\section{Materials and methods}

\section{Study site}

The trial was established outdoor at the Centro de Investigaciones en Café (CICAFE), Heredia, Costa Rica (lat. $10^{\circ} 2^{\prime} 2.88168^{\prime \prime} \mathrm{N}$, long. $\left.84^{\circ} 8^{\prime} 16.12284^{\prime \prime} \mathrm{W}\right)$. The site is located at $1180 \mathrm{~m}$ asl and has an average annual temperature and rainfall of $21.5^{\circ} \mathrm{C}$ and $2650 \mathrm{~mm}$, respectively.

\section{Plant materials}

Eight Arabica coffee cultivars developed by the IAPAR were evaluated. The susceptible cultivars Caturra and Catuaí Vermelho IAC 99 were also included (Table 2). 


\section{Experimental design and conduction of study}

We used a randomized complete blocks design with 10 treatments and 5 replications with 10 plants. The Caturra cultivar was the susceptible control.

The seeds of each cultivar were placed to germinate on Peat moss substrate. On Sept. 25, 2015, the seedlings in the cotyledonal state were individually transplanted in polyethylene bags with $1.3 \mathrm{~L}$ of substrate composed of soil $(50 \%)$, organic fertilizer $(25 \%)$ and rice husk $(25 \%)$. The bags were placed under a double row shade mesh, with $15 \mathrm{~cm}$. The plants were maintained with the necessary care of irrigation, nutrition and disease control to develop properly. The inoculum of $M$. exigua was extracted from a lot naturally infested at CICAFE, where the species had been identified with enzymatic (Hernández, 2007), morphological and molecular (Rojas, 2010) techniques. The inoculation was carried out on Jan. 20, 2016 (117 d after transplanting) with 2500 eggs $+J_{2}$ per plant (initial population $=$ IP), from a liquor solution of roots with galls and sifted through a set of 100 and 500 mesh superimposed screens.

\section{Traits measured and statistical analysis}

The evaluation of the final population (FP) was carried out on Aug. 17, 2016 (209 d after the inoculation), considering the number of eggs $+J_{2}$ in $100 \mathrm{~g}$ of roots of 10 plants per replication and the estimation of gall index (GI) of each plant (Table 3). The statistical program InfoStat (version 1.0, 2001) was used for the ANOVA and comparison of means with the Fisher LSD test $(\alpha=0.05)$, from homogeneous variances. With the population density data, the reproduction factor (RF) was calculated using the formula: RF = FP / IP (Oostenbrink, 1966). To classify the resistance levels, the reduction in the reproduction factor (RRF) of $M$. exigua of each cultivar was used in relation to the susceptible control Caturra, with the formula RRF $=\mathrm{RF}$ of the susceptible control - RF of the cultivar / RF of the susceptible control x 100 (Moura and Regis, 1987). Based on the RRF values, the cultivars were classified according to the criteria of Shigueoka et al. (2017), being: < 25.00\% = highly susceptible (HS); 25.00 to $49.99 \%$ = susceptible (S); 50.00 to $74.99 \%=$ moderately susceptible (MS); 75.00 to $89.99 \%$ = moderately resistant (MR); 90.00 to $94.99 \%$ = resistant (R); 95.00 to $100 \%=$ highly resistant $(H R)$.

\section{Conclusion}

Under the conditions in which this research was developed, the cultivars IAPAR 59 and IPR 98 were resistant to Meloidogyne exigua, native of Costa Rica. The IPR 99, IPR 100, IPR 102, IPR 103 and IPR 107 were stood out for their high resistance to this nematode.

\section{References}

Alpizar E, Etienne H, Bertrand B (2006) Intermediate resistance to Meloidogyne exigua root-knot nematode in Coffea arabica. Crop Prot. 26:903-910.

Andreazi E, Sera GH, Faria RT de, Sera T, Fonseca IC de B, Machado ACZ, Shigueoka LH, Carvalho FG, Carducci FC (2015) Behavior of 'IPR 100' and 'Apoatã IAC 2258' coffee cultivars under different infestation levels of Meloidogyne paranaensis inoculum. Aust J Crop Sci. 9:1069-1074.

Anthony F, Topart P, Martinez A, Silva M, Nicole M (2005) Hypersensitive-like reaction conferred by the Mex-1 resistance gene against Meloidogyne exigua in coffee. Plant Pathol. 54:476-482.

Baeza CA, Benavides M, Leguizamón JE (1978) Plantas de la zona cafetera colombiana hospedantes de especies de Meloidogyne Goeldi. Cenicafe. 29:35-45.

Barbosa DHSG, Vieira HD, Souza RM, Viana AP, Silva CP (2004) Field estimates of coffee yield losses and damage threshold by Meloidogyne exigua. Nematol Brasil. 28:4954.

Bertrand B, Aguilar G, Bompard E, Rafinon A, Anthony F (1997) Comportamiento agronómico y resistencia a las principales enfermedades y plagas de líneas de Sarchimores y Catimores en Costa Rica. Plantations recherche, développement 4:312-321.

Bertrand B, Anthony F, Lashermes P (2001) Breeding for resistance to Meloidogyne exigua in Coffea arabica by introgression of resistance genes of Coffea canephora. Plant Pathol. 50:637-643.

Bertrand B, Borbón O, Aguilar G (1998) Situación nematológica en un cafetal de la meseta central de Costa Rica y posibilidades de control. In: Zamora L (ed) Resultados y avances de investigación. ICAFE, San José. p. 15-28.

Carneiro RMDG, Mesquita LFG de, Gonçalves W, Pereira AA (2008) Pathogenicity of Meloidogyne spp. (Tylenchida: Meloidogynidae) from Brazil and Central America on two genotypes of Coffea arabica. Trop Plant Pathol. 33:309312.

Dias PP, Vieira HD, Gomes DHS, Viana AP, Gonçalves W, Bastos WE de (2009) Avaliação do desenvolvimento vegetativo e do comportamento de mudas de café (Coffea arabica) infectadas ou não por uma população Fluminense de Meloidogyne exigua. Coffee Sci. 4:1-10.

Dias-Arieira CR, Melo S de, Chiamolera FM, Biela F, CunhaChiamolera TPL, Puerari HH, Fontana LF (2012) Behavior of coffee plants IPR 100 and IPR 106 in soil infested with Meloidogyne incognita. J Food Agric Environ. 10:251-255.

Gonçalves W, Pereira AA (1998) Resistência do cafeeiro a nematóides: IV - Reação de cafeeiros derivados do Híbrido de Timor a Meloidogyne exigua. Nematol Brasil. 22: 39-50.

Gonçalves W, Silvarolla MB (2007) A luta contra a doença causada pelos nematóides parasitos do cafeeiro. O Agronômico. 59:54-56.

Hernández A (2007) Caracterización de la diversidad de nemátodos agalladores (Meloidogyne sp.) asociados al cultivo del cafeto de Centroamérica. Boletín IICAPROMECAFE. 112:8-11.

Hernández A, Fargette M, Sarah J (2004) Pathogenicity of Meloidogyne spp. (Tylenchida: Meloidogynidae) isolates from Central America and Brazil on four genotypes of coffee. Nematology. 6:205-213.

Humphreys D, Flores L, Gómez M, Salazar L, Gómez L, Elling A (2014) Meloidogyne lopezi n. sp. (Nematoda: Meloidogynidae), a new root-knot nematode associated with coffee (Coffea arabica L.) in Costa Rica, its diagnosis and phylogenetic relationship with other coffeeparasitising Meloidogyne species. Nematology. 16:643661. 
ICAFE (1998) Manual de recomendaciones para el cultivo del café. Centro de Investigaciones en Café, Heredia.

INEC (2015) VI Censo Nacional Agropecuario. INEC, San José. Ito DS, Sera GH, Sera T, Santiago DC, Kanayama FS, Grossi L. del (2008) Progênies de café com resistência aos nematóides Meloidogyne paranaensis e raça 2 de Meloidogyne incognita. Coffee Sci. 3:156-163.

Jaehn A, Rebel EK, Matiello JB (1984) Viabilidade de recuperação de mudas de cafeeiro infestadas por Meloidogyne incognita através de nematicidas. Nematol.. Brasil. 8:295-300.

Kanayama FS, Sera GH, Sera T, Mata JS da, Ruas PM, Ito DS (2009) Progênies de Coffea arabica cv. IPR 100 com resistência ao nematóide Meloidogyne incognita raça 1 . Ciência Agrotecn. 33:18.

Leguizamón JE, López S (1972) Nematodos en plantaciones de café en Colombia. Avances Técnicos Cenicafé. 20:1-4.

López R, Salazar L (1989) Meloidogyne arabicida sp., n. (Nemata: Heteroderidae) nativo de Costa Rica: un nuevo y severo patógeno del cafeto. Turrialba. 39:313-323.

Marcolan AL, Ramalho AR, Mendes AM, Domingues CA, Freitas C de, Medeiros JN, Vieira JR, Magalhães SJ de, Fernandes S, Veneziano W (2009) Cultivo dos Cafeeiros Conilon e Robusta para Rondônia. 3rd ed. Embrapa Rondônia/EMATER-RO, Porto Velho.

Moura R, Regis EMO (1987) Reações de cultivares de feijoeiro comum (Phaseolus vulgaris) em relação ao parasitismo de Meloidogyne javanica e $M$. incognita. Nematol Brasil. 11:215-225.

Muniz M de FS, Campos VP, Moita AW, Gonçalves W, Almeida MRA, Sousa FR de, Carneiro RMDG (2009) Reaction of coffee genotypes to different populations of Meloidogyne spp.: detection of a naturally virulent $M$. exigua population. Trop Plant Pathol. 34:370-378.

Noir S, Anthony F, Bertrand B, Combes $M$, Lashermes $P$ (2003) Identification of a major gene (Mex-1) from Coffea canephora conferring resistance to Meloidogyne exigua in Coffea arabica. Plant Pathol. 52:97-103.

Oostenbrink M (1966) Major characteristic of the relation between nematodes and plants. Mededlingen voor Landlb Hoogeschool, Wageningen. 66:3-46.

Pereira AA, Baião AC (2015) Cultivares. In: Sakiyama NS, Martinez HEP, Tomaz MA, Borém A (eds) Café arábica: do plantio à colheita. Edit. UFV, Viçosa. p. 24-45.

Pereira TB, Salgado SML, Rodrigues G, Pereira AA, Ferreira $A D$, Oliveira LPV (2012) Reação de genótipos de cafeeiro (Coffea arabica L.) a Meloidogyne exigua população Sul de Minas. Coffee Sci. 7:84-90.
Rezende RM, Andrade VT, Salgado SML, Rezende JC de, Oliveira J de, Carvalho GR (2017) Genetic gain in the resistance of arabica coffee progenies to root-knot nematode. Crop Sci. 57:1355-1362.

Rodrigues AC, Abrantes IM, Melillo MT, Bleve-Zacheo T (2000) Ultrastructural response of coffee roots to rootknot nematodes, Meloidogyne exigua and $M$. megadora. Nematropica. 30:201-210.

Rojas M (2010) Caracterización morfológica y molecular de Meloidogyne spp. en plantaciones de café en Costa Rica. Informe de Investigaciones 2008. Instituto del Café de Costa Rica, San José.

Rojas M, Salazar L (2013) Densidad crítica de Meloidogyne exigua en plantas de almácigo de café variedad Caturra. Agronomía Costarricense. 37:115-123.

Salas L, Echandi E (1961) Nemátodos parásitos en plantaciones de café de Costa Rica. Café (Costa Rica). 3:2124.

Salgado SML, Campos VP, Resende MLV, Krzyzanowski AA (2002) Reprodução de Meloidogyne exigua em cafeeiros lapar-59 e Catuaí. Nematol Brasil. 26:205-207.

Salgado SML, Resende ML, Campos VP (2005) Reprodução de Meloidogyne exigua em cultivares de cafeeiros resistentes e suscetíveis. Fitopatol Brasil. 30:413-415.

Sera T, Sera GH, Fazuoli LC, Machado ACZ, Ito DS, Shigueoka LH, Silva SA da (2017) IPR 100 - Rustic dwarf Arabica coffee cultivar with resistance to nematodes Meloidogyne paranaensis and $M$. incognita. Crop Breed. Applied Biotech. 17:175-179.

Shigueoka LH, Sera T, Fonseca IC de B, Andreazi E, Carducci FC, Sera GH (2017) Coffea arabica lines with resistance to nematode Meloidogyne paranaensis derived from crossings with IPR 100. Aust J Crop Sci. 11:1203-1209.

Silva RV, Oliveira RDL, Nascimento KJT, Rodrigues FA (2010) Biochemical responses of coffee resistance against Meloidogyne exigua mediated by silicon. Plant Pathol. 59: 586-593.

Silva RV, Oliveira RDL, Pereira AA, Seni DJ (2007) Respostas de genótipos de Coffea spp. a diferentes populações de Meloidogyne exigua. Fitopatol Brasil. 32:205-212.

Silvarolla MB, Gonçalves W, Lima MMA (1998) Resistência do cafeeiro a nematóides $\mathrm{V}$ - Reprodução de Meloidogyne exigua em cafeeiros derivados da hibridação de Coffea arabica com C. canephora. Nematol Brasil. 22:51-59.

Villain L, Anzueto F, Hernández A, Sarah J (1999) Los nematodos parásitos del cafeto. In: Bertrand B, Rapidel B (eds) Desafíos de la caficultura en Centroamérica. IICA/PROMECAFE, CIRAD, IRD, CCCR, FRANCIA, Costa Rica. p. 327-367. 